\title{
Selective estrogen receptor modulators (SERM): A new choice for postmenopausal women and physicians who worry on cancer
}

\author{
A. Baziad
}

\begin{abstract}
Abstrak
Pascamenopause dicirikan dengan berhentinya haid, hilangnya fungsi ovarium, dan menurunnya kadar estrogen secara dramatik. Berkurangnya estrogen menyebabkan timbulnya beberapa masalah kesehatan seperti penyakit kardiovaskuler, osteoporosis dan demensia. Pemberian estrogen terbukti efektif untuk pengobatan dan pencegahan keluhan jangka pendek dan panjang. Namun demikian, hingga kini jumlah pemakai HRT masih rendah. Takut akan kanker payudara dan kanker endometrium merupakan ketakutan utama dalam menggunakan HRT, meski hubungan antara penggunaan HRT jangka panjang dan kanker payudara serta kanker rahim masih belum jelas. Bagi dokter maupun pasien yang takut akan kanker, sekarang telah tersedia selective estrogen receptor modulators (SERM) dengan nama generik raloksifen. (Med J Indones 2001; 10: 187-90)
\end{abstract}

\begin{abstract}
The postmenopausal state is characterized by the cessation of menstruation, loss of ovarian function, and a dramatic decrease in the level of circulating estrogen. This state of estrogen deficiency contributes to the acceleration of several age-related health problems in women, including cardiovascular disease, osteoporosis, and dementia. Estrogen replacement is clearly effective in the short-term and long-term treatment and prevention of postmenopausal symptoms. However, until now, the amount of HRT user is still very low. Fear of breast cancer and endometrial cancer are the most common concern in using hormone replacement therapy (HRT), although the relationship between long-term HRT and breast cancer remains controversial. For physicians or patients, who worry on cancer, the ideal drug is now available i.e. the selective estrogen receptor "modulators (SERM), with the generic name raloxifine. (Med $J$ Indones $2001 ; 10: 187-90$ )
\end{abstract}

Keywords: HRT, raloxifine, osteoporosis, CVD, tamoxifen

Administration of hormone replacement therapy (HRT) is effective in both treating the acute symptoms of menopause and protecting against the development of osteoporosis, vascular disease, dementia, stroke, and colon cancer, it is initiated soon after menopause.

Until now, the amount of HRT user is still very low, though it is already well known that HRT has a lot of beneficial effects for relieving the menopausal symptoms or complications. However, either physicians or patients still worry to use this HRT. Fear of breast cancer and endometrial cancer becomes the biggest reason why they do so. Although the progestin in HRT might inhibit the proliferative effect of estrogen

Department of Obstetrics and Gynecology, Faculty of Medicine, University of Indonesia/Dr. Cipto Mangunkusumo Hospital, Jakarta, Indonesia on endometrium, recent data indicated that long-term HRT might still be associated with an increase of uterine cancer. ${ }^{1}$

Increased risk of breast cancer in women who take estrogens remains a controversial issue, but most recent data have confirmed a higher risk in women taking full-dose HRT for a long time. ${ }^{2,3}$ The use of HRT is also associated with other side effects, including the resumption of menstrual bleeding, breast tenderness, water retention, and lower abdominal cramps.

Because of the side effects and feared liabilities of HRT, physicians prescribe HRT infrequently, and long-term compliance in women receiving HRT is very poor. It was estimated that less than $20 \%$ of postmenopausal women were prescribed HRT in the USA, and greater than $75 \%$ of those HRT receiver 
discontinued its use within 3 years. $^{4}$ From 1054 postmenopausal women that were collected from the "Menox" menopause clinic, Jakarta, only $62 \%$ of the patients kept using HRT for 1 year, 18\% kept using HRT for 2 years, and 12\% kept using HRT for 3 years. ${ }^{5}$ Thus, a therapy with a better safety profile, better long-term compliance, is needed.

For menopausal women or physicians, who worry about breast cancer and endometrial cancer, the ideal drug is now available, i.e. selective estrogen receptor modulators (SERM), with the generic name raloxifine.

The purposes of this review are to discuss the need to improve the treatment and prevention of post menopausal conditions such as osteoporosis and cardiovascular disease, and to introduce the concept of selective estrogen receptor modulator (SERM) as a potential alternative to HRT for women or physicians, who worry about cancer.

\section{DEVELOPMENT OF IDEAL DRUGS: ANTI- ESTROGENS ( THE SERM CONCEPT)}

Recently, the search for a safer, more acceptable form of HRT has led to the evaluation of several classes of organic compounds grouped together as "antiestrogens", including the triphenylethylene tamoxifen and benzothiophene raloxifine. They were termed selective estrogen receptor modulators (SERM). Selective estrogen receptor modulators (SERM) are agents that bind to estrogen receptor, and produce estrogen-like effects in some tissues, but block the effects of estrogen in other. ${ }^{6,7}$

Raloxifine was originally investigated as a therapy for advanced breast cancer, and is currently under development for prevention and treatment of osteoporosis and cardiovascular disease in postmenopausal women.

\section{SERM: PREVENTION OF OSTEOPOROSIS}

The estrogen agonist-like effects of raloxifine on the skeleton have been intensively studied. In a study using ovariectomized rats, raloxifine produced estrogenlike prevention of bone loss. ${ }^{8}$ Bone turnover is decreased with raloxifine, in a manner similar to that seen with various estrogen treatment. In trials involving over 10,000 postmenopausal women treated for over 3 years with raloxifine, bone turnover was decreased, with $2.3 \%$ increase in bone mineral density at all skeletal sites. ${ }^{9}$ In a 3-year study of nearly 8000 osteoporotic women, a 40-50\% decrease in vertebral fracture rate was achieved by daily therapy with raloxifine. In addition, the multiple outcomes of raloxifine evaluation in postmenopausal women with osteoporosis showed that raloxifine increased bone mineral density in the spine and femoral neck, and reduced the risk of vetebral fracture. ${ }^{10}$ Raloxifine is chemically distinct from tamoxifen and estradiol. It binds estrogen receptors and block estrogen-induced DNA transcription in the breast and endometrium. ${ }^{11}$ In an animal study, raloxifine inhibited estrogenstimulated growth of mammary cancers. ${ }^{12}$

\section{SERM : PREVENTION OF CARDIOVASCULAR DISEASE}

As a women enters menopause, an increase in LDL cholesterol and a decrease in HDL cholesterol level are observed. The incidence of cardiovascular disease is related to the serum levels of HDL and LDL. A high level of HDL has been shown to reduce the risk of cardiovascular disease. ${ }^{13}$

Raloxifine treatment lowered serum cholesterol level of ovariectomized rats and rabbits. ${ }^{14}$ The hypolipidemic effects required binding to estrogen receptor. Clinical studies in humans have demonstrated that raloxifine, at a dose of $200 \mathrm{mg} / \mathrm{d}$ or $600 \mathrm{mg} / \mathrm{d}$ for 2 months, significantly decreased LDL-C level by $9 \%$ to $12 \% .{ }^{15}$ This was comparable to the $11 \%$ decline seen with conjugated estrogen $0.625 \mathrm{mg} / \mathrm{d}$. In other study by Walsh et.al., ${ }^{16}$ raloxifine favorably altered biochemical markers of cardiovascular risk by decreasing LDL-C, fibrinogen, and lipoprotein, and by increasing HDL2-C without raising triglycerides. In contrast to HRT, raloxifine had no effect on HDL-C and plasminogen activator inhibitor-1 (PAI-1), and had a lesser effect on HDL2-C.

Whether raloxifine has effects on other risk factors for cardiovascular disease, such us blood pressure, vascular tone, and hyperinsulinaemia, further clinical trials are needed.

\section{SERM : ANTAGONIST EFFECTS IN REPRODUCTIVE TISSUE}

Although raloxifine mimics the activity of estrogen in bone, and on LDL, and cholesterol metabolism, in 
reproductive tissue raloxifine acts as a pharmacologic antagonist of estrogen. In a study, raloxifine produced a potent blockade of the estrogen-induced stimulation of various tissues in reproductive system. ${ }^{17}$ In another study, raloxifine inhibited estrogen dependent proliferation of human MCF-7 breast cancer cells in vitro, and inhibited the development of carcinogen induced mammary tumors in rats. Raloxifine also had an estrogen-antagonistic effects on uterus, producing minimal endometrial stimulation in ovariectomized rats. ${ }^{18}$ Although raloxifine does not cause uterine stimulation, and is a potent estrogen antagonist in breast and uterus, long-term effects of raloxifine on the incidence of uterine and breast cancer remain to be established, if it is intended to replace HRT.

A serious side effect from raloxifine is venous thromboembolism. Other side effect is mild to moderate hot flashes.

\section{TAMOXIFEN AS A SERM}

Tamoxifen was first used in the early 1970s to treat advanced breast cancer, and is now the most widely used cancer drug in the world. ${ }^{19}$ Recently, however, there has been interest in using it as an HRT substitute in women with a history of breast cancer. During clinical studies using tamoxifen in the prevention of breast cancer in women, it was revealed that this agent exerted beneficial effects on bone, increasing bone mineral density and lowering LDL-C. ${ }^{20,21}$ Furthermore, women with breast cancer on chronic tamoxifen therapy experienced a $50 \%$ decrease in mortality due to coronary artery disease, supporting the cardioprotective actions of this SERM. ${ }^{22}$

The approval of tamoxifen for the prevention of breast cancer has refocused attention on the side effects of this drug. Tamoxifen however has a partial estrogen agonist effect in the uterus, stimulating endometrial proliferation and increasing the incidence of endometrial polyps. ${ }^{22,23}$ Long-term treatment with tamoxifen is associated with a two to seven fold increase in the risk of endometrial cancer. ${ }^{24,25}$ There is also evidence that tamoxifen, even at low doses, induces ocular toxicity, including corneal changes, cataracts, and retinopathies. $^{26,27}$ In the most recent prospective study, tamoxifen was associated with decreased visual acuity, bilateral macular edema, yellow-white dots in the paramacular and fovea areas, and corneal opacities. After tamoxifen withdrawal, these changes were reversed except for the retinal opacities. $^{28}$

\section{CONCLUSIONS}

SERM represents an alternative approach to the use of HRT for decreasing postmenopausal bone loss, as well as for reducing the incidence of CVD. Tamoxifen, the first SERM available for clinical use, has been shown to increase the risk of endometrial proliferation, polyps, and ocular toxicity. Thus, its clinical utility may be limited. In contrast, raloxifine has little or no effect on the uterus and breast. Because of its more selective action, raloxifine may be a good choice for postmenopausal women or physicians, especially for those who are unwilling or worry to use HRT.

\section{REFERENCES}

1. Beresfold SA, Weiss NS, Voigt LF, Mc Knight B. Risk of endometrial cancer in relation to use of oestrogen combined with cycle progesteron therapy in postmenopausal women. Lancet 1997;349:458.

2. Coldizt GA, Haukinson SE, Hunter DJ. The use of estrogen and progestin and the risk of breast cancer in postmenopausal women. N Engl J Med 1995;332:1589.

3. Stamford JL, Weiss NS. Combined estrogen and progestin hormonal replacement therapy in relation to risk of breast cancer in middle -aged women. JAMA 1995;274:137.

4. Ravnikar VA. Compliance with hormone replacement therapy: Are women receiving the full impact of hormone replacement therapy preventative health benefits? Women's Health Issues 1992;2:75.

5. Baziad A. A restrospective study of menopausal women in a private menopause clinic "Menox", Jakarta, from December 1996 to December 1999. In press.

6. Jordan VC. At the cutting edge: The only one antiestrogen is no estrogen. Mol Cell Endocrinol 1990;74:91-5.

7. Draper MW, Flowers DE, Neild DA, Huster WJ, Zerbe RL. Antiestrogenic properties of raloxifine. Pharmacology 1995;50:209-17.

8. Bryant HU, Magee DE, Cole HW. Beneficial effects of etinylestradiol and raloxifine in the ovariectomized rat are dependent on an intact pituitary. J Bone Miner Res 1994; 9:135.

9. Draper MW. SERM: A new option for estrogen therapies in prevention of osteoporosis. 10 th Congress of the Asean Federation of Endocrine Societies (AFES). Lunch symposium, $2^{\text {nd }}$ Dec 1999, Bangkok.

10. Ettinger B, Dennis MB, Bruce HM, Knickerbocker RK, Nickelsen T, Genant HK. Reduction of verebral fracture 
risk in postmenopausal women with osteoporosis treated with raloxifine. JAMA 1999;7:637.

11. Bizozwski AM, Pike AC, Danser Z. Molecular basis of agonism and antagonism in the oestrogen receptor. Nature 1997;389:753-8

12. Anzano MA, Peer CW, Smith JM. Chemoprevention of mammory carcinogenesis in the rat: combined use of raloxifine and cis-retinoid acid. I Natl Cancer Inst 1996; 88:123-5.

13. Gordon T, Castelli WP, Hjortland MC, Kannel WB. High density lipoprotein as a protective factor against coronary heart disease: the Framingham study. Am J Med 1997;62:701-4.

14. Bjamason N, Haarbo J, Byrjalsen I, Kaufmann R, Christiansen $\mathrm{C}$. Raloxifine inhibits aortic accumulation of cholesterol in ovariectomized, cholesterol-fed rabbits. Circulation 1997;96:1964-9.

15. Draper MW, Flowers DE, Neild DA, Harper KD, Arnaud C. A controlled trial of raloxifine (LY 139481) HCL: Impact on bone turnover and serum lipid profile in healthy postmenopausal women. J Bone Mineral Res 1996;11:835-42.

16. Bryant HU, Willard HD. Selective estrogen receptor modulators: an alternative to hormone replacement therapy. Indianapolis: Ely Lilly; 1998.

17. Black LJ, Jones CD, Falcone JF. Antogonism of estrogen action with a new benzothiophene-derived antiestrogen. Life Sci 1983;32:1031

18. Sherwin BB. Estrogen and/or androgen replacement therapy and cognitive functioning in surgically menopause women. Psychoneuroendocrinology 1988;13:345-57

19. Cole MP, Jones CT, Todd ID. A new anti-oestrogenic agent in late breast cancer. An early clinical appraisal of ICI46474. Br J Cancer 1971;25:270-5.
20. Love RR, Mazess RB, Barden HS, Epstein S, Newcomb PA, Jordan VC, et al. Effects of tamoxifen on bone mineral density in postmenopausal women with breast cancer. N Engl J Med 1992;326:852-6.

21. Love RR, Newcomb PA, Wiebe DA, Surawicz TS, Jordan VC, Carbone PP, et al. Effects of tamoxifen on lipid and lipoprotein levels in postmenopausal patients with nodenegative breast cancer. J Natl Cancer Inst 1990;82:132732.

22. Mc Donald CC, Alexander FE, Whyte BW, Forrest AP, Stewart HJ. Cardiac and vascular morbidity in women receiving adjuvant tamoxifen for breast cancer in a randomised trial:The Scottish Cancer Trials Breast Group. Br Med J 1995;311:977-80.

23. Cohen I, Altaras MM, Shapira J, Tepper R, Rosen DJ, Cordoba $\mathrm{M}$, et al. Time-dependent effect of tamoxifen therapy on endometrial pathology in asymptomatic postmenopausal breast cancer patients. Int $\mathrm{J}$ Gynecol Pathol 1996;15:152-7.

24. Fisher B, Constantino JP, Redmont CK, Fisher ER, Wickerham DL, Cronin WM. Endometrial cancer in tamoxifen-treated breast cancer patients: Findings from the National Surgical Adjuvant Breast and Bowel Project (NSABP) B-14. J Natl Cancer Inst 1994;86:527-37.

25. Magriples U, Naftolin F, Schwrtz PE, Carcangiu ML. High-grade endometrial carcinoma in tamoxifen-treated breast cancer patients. J Clin Oncol 1993;1 1:485-90.

26. Kaiser-Kupfer MI, Lippman ME. Tamoxifen retinopathy. Cancer Treat Rep 1978;62:315-20.

27. McKeown CA, Swartz M, Blom J, Maggiano JM. Tamoxifen retinopathy. Br J Ophtalmol 1981;65:177-9.

28. Pavlidis NA, Petris C, Briassoulis E. Clear evidence that long-term, low dose tamoxifen treatment can induce ocular toxicity. Cancer 1992;69:2961-4. 